\title{
Serum prolactin response to metoclopramide during status epilepticus
}

Karolinska Institute at Södersjukhuset, Stockholm, Sweden Department of Neurology $\mathrm{U}$ Lindbom T Tomson

Department of Clinical

Neurophysiology BY Nilsson

Department of Internal Medicine II D E H Andersson Correspondence to: Dr Lindbom, Department of Neurology, Södersjukhuset, S-100 64 Stockholm, Sweden.

Received 18 March 1991 and in revised form 7 October 1991 Accepted 20 November 1991

\begin{abstract}
Transient elevation of serum prolactin frequently follows generalised tonicclonic and complex partial seizures. However, the levels of prolactin during status epilepticus are not increased above the normal range. Exhaustion of central prolactin supplies has been proposed as a possible mechanism for the absence of prolactin increase during status epilepticus. To test this hypothesis we injected intravenous metoclopramide $(10 \mathrm{mg})$ in eight consecutive patients with status epilepticus. One patient had generalised tonic-clonic status epilepticus. Seven patients had EEG-verified non-convulsive status epilepticus, consisting of one typical absence status, one atypical absence status and five complex partial status epilepticus. Metoclopramide raised the mean (SD) prolactin levels at least fivefold in all patients, from $5.8(8.0) \mu \mathrm{g} / 1$ to $87.0(39 \cdot 0) \mu \mathrm{g} / \mathrm{l}$, within 60 minutes after the injection. Thus the mechanism for low prolactin values in status epilepticus is not cellular depletion of stored prolactin, but more likely an altered regulation, presumably induced by prolonged seizure activity.
\end{abstract}

$(\Im$ Neurol Neurosurg Psychiatry 1992;55:685-687)

Generalised tonic-clonic and complex partial seizures are followed by a transient increase of serum prolactin in about $70-90 \%$ of the cases. ${ }^{1-9}$ Peak values are seen 1 15-20 minutes after the seizures. Prolactin levels thereafter decline to baseline values within 180 minutes Most simple partial seizures are not accompanied by any significant increase of prolactin. $^{349}$ As for absence seizures, changes in serum prolactin from baseline values have not been reported but the published cases are few and the duration of siezures short. ${ }^{1011}$ There seems to be a lower limit of 30 seconds of seizure activity necessary to cause elevation of prolactin in serum. ${ }^{31112}$ Prolactin levels in status epilepticus do not seem to differ from baseline values irrespective of the type of status. $^{12-14}$ Thus in the clinical situation a normal prolactin value must be interpreted with caution in the differentiation between epileptic and pseudoseizures.

The regulation of prolactin is not completely known but the predominant control mechanism is inhibitory, mediated mainly by dopamine. ${ }^{1516}$ In relation to single epileptic seizures the changes in prolactin levels may be due to abnormal activity within the areas of the central nervous system that regulate prolactin release. Dana-Haeri et $\mathrm{al}^{3}$ have suggested that spread of seizure activity from medial temporal structures to the hypothalamic nuclei leads to changes in prolactin output. This agrees with the findings of Sperling et $a l^{9}$ that simple partial seizures involving limbic structures is accompanied by increased levels of prolactin. Jackel et $a^{14}$ and Trimble ${ }^{12}$ have proposed depletion of stored prolactin as an explanation for the absence of prolactin increase after prolonged seizure activity. To test this hypothesis we injected a dopamine receptor blocker, metoclopramide, in patients with status epilepticus.

\section{Patients and methods}

Eight consecutive patients (five male, three female) with status epilepticus were studied. Ages ranged from 55-74 years, median 67 years. Nonconvulsive status epilepticus was confirmed with ictal EEG recording. Patients with focal ictal EEG seizure activity and impaired consciousness without convulsions were classified as having complex partial status epilepticus $^{17}$ according to the criteria of Mayeux and Lueders. ${ }^{16}$ Nonconvulsive status with generalised EEG seizure activity was designated as absence status. If the generalised discharges were rhythmic spike-wave at $3 \mathrm{~Hz}$, the status was classified as a typical absence status. Patients with generalised seizure activity other than $3 \mathrm{~Hz}$ spike waves were classified as having atypical absence status ${ }^{18}$ in accordance with the classification by Gastaut. Two patients had absence status, one typical and one atypical. Five patients were classified as having complex partial status epilepticus and one patient had generalised tonic-clonic status epilepticus. This patient did not have ictal EEG recording since this would have caused an unacceptable delay in treatment of the status. His clinical symptoms, observed at the hospital, were, however, typical for the diagnosis. Another criterion for inclusion was that intravenous injection of diazepam in patients with nonconvulsive status epilepticus should have effect on the seizure activity in EEG since the clinical response to treatment in these patients was not easily perceived. All patients with nonconvulsive status epilepticus showed similar clinical symptoms: fluctuating stupor, disorientation, extreme latency for monosyllabic answers, if any, and a tendency to perseveration in verbal communication. Verbal and motor inactivity were striking even in patients who seemed awake. Automatisms and 
Table Clinical data on eight patients with status epilepticus

\begin{tabular}{|c|c|c|c|c|}
\hline Patient & $\begin{array}{l}\text { Age/Duration } \\
\text { of epilepsy (years) }\end{array}$ & Type of status & $\begin{array}{l}\text { Duration of status } \\
\text { (hours) }\end{array}$ & $\begin{array}{l}\text { Drug therapy } \\
\text { (mg/day) }\end{array}$ \\
\hline 1 & $71 / 32$ & Typical absence & 7 & $\begin{array}{l}\text { Carbamazepine (400) } \\
\text { Ethosuximide (500) } \\
\text { Phenobarbital (15) }\end{array}$ \\
\hline 2 & $67 / 3$ & Atypical absence & 4 & Carbamazepine (200) \\
\hline 3 & $63 / 5$ & Complex partial & 30 & Phenytoin (300) \\
\hline 4 & $55 / 7$ & Complex partial & 10 & Carbamazepine (800) \\
\hline 5 & $69 / 0 x)$ & Complex partial & 5 & \\
\hline & $69 / 0$ & Complex partial & 7 & Carbamazepine (400) \\
\hline 6 & $74 / 0 \mathrm{x})$ & Complex partial & 300 & \\
\hline 7 & $65 / 1$ & Complex partial & 28 & Phenytoin (250) \\
\hline 8 & $61 / 4$ & Generalised tonic-clonic & 1 & Phenytoin (?) \\
\hline
\end{tabular}

x) Status epilepticus was the first manifestation of epilepsy.

myoclonic jerks were often discrete. Six of the patients had a previous history of epilepsy ranging from a few months to 33 years, all of whom were under continuous treatment with anticonvulsant drugs (table). In two of the patients, both with complex partial status epilepticus, status was the first manifestation of epilepsy.

Serum prolactin was determined before (ictal value) and after the administration of metoclopramide. One or, when possible, two ictal blood samples were drawn from an antecubital vein immediately before treatment of status. Status was then terminated with 5-10 $\mathrm{mg}$ of intravenous diazepam. Ten $\mathrm{mg}$ of intravenous metoclopramide was given during status or within 15 minutes after its termination. Further blood samples were obtained 15, $30,60,90,120$ and 180 minutes after the metoclopramide injection. One patient (5) was admitted to the hospital with status epilepticus twice within a few months. On the first occasion metoclopramide was given immediately after the termination of status and on the second occasion during status, before treatment. A control experiment was conducted in three patients, one with typical absence status and two with complex partial status. In these patients the metoclopramide injection and blood sampling were repeated at least 5 days after the first injection and after at least 24 seizure free hours. The second injection of metoclopramide was given at the same time of the day as the first. Serum samples were stored at $-20^{\circ} \mathrm{C}$ until analysis by radioimmunoassay. ${ }^{19}$ Normal serum prolactin levels at our laboratory are less than $25 \mu \mathrm{g} / 1$. The study was approved by the local Ethical Committee.

\section{Results}

Ictal levels of serum prolactin and responses to metoclopramide injections are shown in fig 1. None of the patients had an ictal level above the normal range. Six out of eight patients had ictal levels below $5 \mu \mathrm{g} / \mathrm{l}$. All eight patients showed at least a five-fold increase in prolactin concentrations within 60 minutes after the metoclopramide injection.

Mean (SD) ictal values were $5.8(8.0) \mu \mathrm{g} / 1$ and mean (SD) peak prolactin levels after metoclopramide were $87.0(39.0) \mu \mathrm{g} / \mathrm{l}$. There was no obvious difference between the various types of status in the response to metoclopramide. One patient was studied twice with two separate episodes of status, on the first occasion before, and on the other after treatment with diazepam. The prolactin responses to metoclopramide were similar. In three patients the effect of metoclopramide was studied also under baseline conditions. The values obtained after at least 24 hours without seizures did not differ from the responses in connection with status. Two patients (5 and 6 ) were without anticonvulsant medication at the time of the status, but at the time the baseline values were obtained they were under treatment with carbamazepine in steady-state.

\section{Discussion}

Knowledge of the regulation of prolactin under physiological conditions is incomplete. Two major factors, prolactin-inhibiting factor and prolactin-releasing factor, regulate prolactin secretion. The chemical identities of the prolactin-inhibiting factor and to prolactin-releasing factor still need to be clarified. In contrast to other pituitary hormones, the neuroendocrine control of prolactin is predominantly inhibitory. The major physiologic inhibitor appears to be dopamine, but gamma-aminobutyric acid has been suggested to be a part of nondopamine prolactin-inhibiting factor. ${ }^{15} 16$ Thyrotropin-releasing hormone and vasoactive intestinal polypeptide have been suggested as a prolactin-releasing factor. ${ }^{15}$ The temporary increase in serum prolactin after single seizures may be due to spread of abnormal electrical activity to areas of the central nervous system that regulate prolactin release. ${ }^{3}$ The seizure activity is presumed either to suppress the prolactin-inhibiting factor or to stimulate the prolactin-releasing factor.

It appears that seizure-induced prolactin

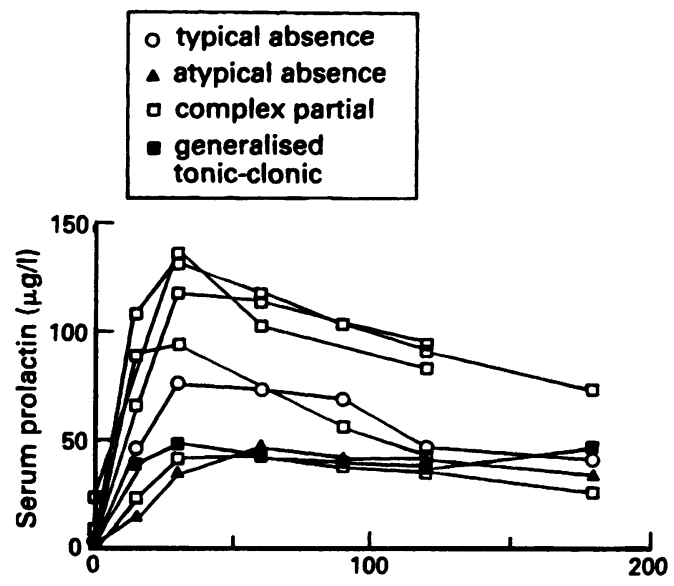

Time after metoclopramide injection ( $\mathrm{min}$ )

Figure Prolactin response to metoclopramide in eight patients with status epilepticus. Blood samples at time zero were drawn before or within 15 minutes after the status was terminated. 
release, apart from the localisation, is dependent on the duration of seizure activity. A seizure duration of at least 30 seconds appears to be necessary to induce an increased prolactin concentration. ${ }^{31112}$ However, with repeated seizures there seems to be a reduction in prolactin response. ${ }^{14}$ In connection with seizure activity of a more extreme duration, such as status epilepticus, the prolactin levels are similar to basal conditions. ${ }^{13}$ We have presented ictal prolactin values during 19 episodes of status epilepticus (this study and reference 13), four generalised tonic-clonic status, eight complex partial status, one typical and six atypical absence status epilepticus. None of these patients showed increased prolactin levels during status epilepticus.

The absence of increased levels of prolactin after prolonged seizure activity may be due to depletion of stored prolactin. ${ }^{12}{ }^{14}$ We tested this hypothesis by giving metoclopramide, a dopamine receptor blocker, in status epilepticus. The response to metoclopramide was prompt and the increase of prolactin at least five-fold in all patients. Furthermore, the response to metoclopramide was, in three of our patients, the same during status as during baseline conditions. While five out of eight patients in our study had complex partial status epilepticus, typical and atypical absence status and generalised tonic-clonic status epilepticus were only represented in one case each. Ictal levels within the normal range $(<25 \mu \mathrm{g} / \mathrm{l})$ and evident response to metoclopramide were the results in all patients independent of the type of status. Hence, even though absence status and generalised tonic-clonic status were represented by single cases only, our results indicate that there is no cellular depletion of prolactin in connection with status epilepticus.

Treatment with diazepam might have influenced the ictal prolactin levels as well as the response to metoclopramide. One patient was given metoclopramide with two episodes of status, the first time within 15 minutes after the status was terminated with diazepam and the second time before diazepam was given. There was no difference in the prolactin response to metoclopramide on these two occasions. This agrees with the findings of Wilson et $a l^{20}$ who concluded that diazepam neither affects basal prolactin levels nor the release of prolactin in response to metoclopramide.

The influence of other antiepileptic drugs on prolactin levels are somewhat controversial. Effects of anticonvulsants on the hypothalamic-pituitary axis have been reported but the results deviate. Basal prolactin levels have been reported to increase, ${ }^{20-23}$ to decrease $e^{2425}$ or to be unaltered ${ }^{2627}$ during treatment with anticonvulsant drugs. Monotherapy seemed to have less effect than polytherapy. ${ }^{22}$ Six of our eight patients were on monotherapy, and two patients were without medication since status epilepticus was their first manifestation of epilepsy. However, when the latter were given metoclopramide on a second occasion they were both on medication with carbamazepine. Ictal and baseline responses to metoclopramide did not differ in these two patients. Thus medication with antiepileptic drugs did not apparently influence our results.

The mechanisms behind the finding of prolactin levels not different from baseline values in association with status epilepticus remain obscure. Our results suggest that mechanisms other than cellular depletion of prolactin must be involved.

This study was supported by a grant from the Karolinska Institute.

1 Trimble MR. Serum prolactin in epilepsy and hysteria. $B M \mathcal{F}$ 1978;2:1682.

2 Abbot RJ, Browning MCK, Davidson DLW. Serum prolactin and cortisol concentrations after grand mal seizures. F Neurol Neurosurg Psychiatry 1980;43:163-7.

3 Dana-Haeri J, Trimble MR, Oxley J. Prolactin and gonadotrophin changes following generalised and partial seizures. F Neurol Neurosurg Psychiatry 1983;46:331-5.

4 Collins WCJ, Lanigan O, Callaghan N. Plasma prolactin concentrations following epileptic and pseudoseizures. concentrations following epileptic and pseud

5 Pritchard PB, Wannamaker BB, Sagel J, Nair R, DeVillier C. Endocrine function following complex partial seizures. Ann Neurol 1983;14:27-32.

6 Laxer KD, Mullooly JP, Howell B. Prolactin changes after seizures classified by EEG monitoring. Neurology $1985 ; 35: 31-5$.

7 Bye AME, Nunn KP, Wilson J. Prolactin and seizure activity. Arch Dis Child 1985;60:848-51.

8 Pritchard PB, Wannamaker BB, Sagel J, Daniel CM. Serum prolactin and cortisol levels in evaluation of pseudoepileptic seizure. Ann Neurol 1985;18:87-9.

9 Sperling MR, Pritchard PB, Engel Jr J, Daniel C, Sagel J. Prolactin in partial epilepsy: An indicator of limbic seizures. Ann Neurol 1986;20:716-22.

10 Wroe SJ, Henley R, John R, Richens A. The clinical value of serum prolactin measurement in the differential diagnosis serum prolactin measurement in the differential diagnosis

11 Bilo L, Meo R, Striano S. Serum prolactin evaluation after "minor" generalised seizures monitored by EEG. F Neurol Neurosurg Psychiatry 1988;51:308-9.

12 Trimble MR. Hysteria, hystero-epilepsy and epilepsy. In: Trimble MR, Reynolds EH, eds. What is epilepsy? The clinical and scientific basis of epilepsy. Edinburgh: Churchill Livingstone, 1986;192-205.

13 Tomson T, Lindbom U, Nilsson BY, Svanborg E, Andersson DHE. Serum prolactin during status epilepticus. F Neurol Neurosurg Psychiatry 1989;52:1435-7.

14 Jackel RA, Malkowicz D, Trivedi R, Sussman NM, Eskin BA, Harner RN. Reduction of prolactin response with repetitive seizures. Epilepsia 1987;28:588.

15 Kato Y, Matsushita N, Ohta H, Tojo K, Shimatsu A, Imura $\mathrm{H}$. Regulation of prolactin secretion. In: Imura $\mathrm{H}$, ed. The pituitary gland. New York: Raven Press, 1985:261-78.

16 Leong DA, Frawley LS, Neill JD. Neuroendocrine control of prolactin secretion. Ann Rev Physiol 1983;45:109-27.

17 Mayeux R, Lueders H. Complex partial status epilepticus: case report and proposal for diagnostic criteria. Neurology 1978;28:957-61.

18 Gastaut H. Classification of status epilepticus. In: DelgadoEscueta AV, Wasterlain CG, Treiman DM, Porter RJ, eds. Advances in neurology, Vol 34: Status epilepticus. New York: Raven Press, 1983:15-35.

19 Röjdmark S, Andersson DEH, Sundblad L. Calcium and calcium-antagonistic effects on prolactin and growth hormone responses to thyrotropin-releasing hormone and L-dopa in man. F Clin Endocrinol Metab 1981;53:594-8.

20 Wilson JD, King DJ, Sheridan B. Tranquillisers and plasma prolactin. $B M \mathcal{F} 1979 ; 1: 123-4$.

21 London DR, Loizou LA, Butt WR, Rovei V, Bianchetti G, Morselli PL. The effect of anti-convulsant drugs (AED) on hormonal responses in normal volunteers. In: on hormonal responses in normal volunteers. In: Johannessen SI, Morselli PL, Pippenger CE, et al, eds. Antiepileptic Therapy: Advances in

22 Franceschi M, Perego L, Cavagnini F, Cattaneo AG, Invitti C, Caviezel F, Strambi LF, Smirne S. Effects of long-term antiepileptic therapy on the hypothalamic-pituitary axis in man. Epilepsia 1984;25:46-52.

23 Macphee GJA, Larkin JG, Butler E, Beastall GH, Brodie MJ. Circulating hormones and pituitary responsiveness in young epileptic men receiving long-term antiepileptic medication. Epilepsia 1988;29:468-75.

24 Isojärvi JIT, Myllylä VV, Pakarinen AJ. Effects of carbamazepine on pituitary responsiveness to luteinizing hormone-releasing hormone, thyrotropin-releasing hormone, and metoclopramide in epileptic patients. Epilepsia 1989;30:50-6.

25 Rao ML, Stefan H, Bauer J. Epileptic but not psychogenic seizures are accompanied by simultaneous elevation of serum pituitary hormones and cortisol levels. Neuroendocrinology 1989;49:33-9.

26 Dana-Haeri J, Oxley J, Richens A. Pituitary responsiveness to gonadotrophin-releasing and thyrotrophin-releasing to gonadotrophin-releasing and thyrotrophin-releasing hormones in epileptic patients receiving carb

27 Bonuccelli U, Murialdo G, Martino E, Lecchini S, Bonura ML, Bambini G, Murri L. Effects of carbamazepine on ML, Bambini G, Murri L. Effects of carbamazepine on prolactin secretion in normal subjects and in
subjects. Clin Neuropharmacol 1985;8:165-74. 